\title{
Using Technology to Prepare World Class School Librarians to Deliver Learning and Literacy
}

\author{
Daniel Fuller \\ Assistant Professor \\ San José State University \\ USA \\ Margaret Lincoln \\ Lecturer \\ San José State University \\ USA \\ Linda Swarlis \\ Lecturer \\ San José State University \\ USA
}

The preparation of school librarians for schools in the United States poses challenges significantly different from other library specializations. One difficulty, finding the best method to prepare school librarians, is confounded by the shortage of qualified school librarians. Can a school librarian preparation program using distance independent technologies, effectively prepare world-class school librarians to deliver learning and literacy? The results indicate the goals of the program were met. When compared with other cohorts, the retention rate was significantly lower. The results are discussed and future directions are considered.

\section{Introduction}

The preparation of school librarians for schools in the United States differs from other library specializations. Unlike librarians who work in colleges or universities, public libraries, or special libraries, school librarians must earn a professional license or credential from a state government agency to practice their profession in public schools. The challenge is finding the best method to prepare school librarians and is confounded by the shortage of qualified school librarians. The situation typically results in the state agency issuing stopgap measures in the form of emergency certificates to school librarian candidates who enroll or are enrolled in a teacher librarian services credential preparation program. The essential question is "can a school librarian preparation program using distance independent technologies, effectively prepare world-class school librarians to deliver learning and literacy?" 
The opportunity to explore the answers to the question occurred in early 2007. The San Francisco Public School District (SFUSD) approached the School of Library and Information Science (SLIS) at San José State University (SJSU) after the voters of San Francisco, California passed a funding initiative (Proposition $\mathrm{H}$ ) to create the Public Education Enrichment Fund (PEEF). The administrative staff of the SFUSD Textbooks and Library Media Services (TLMS) wanted to partner with SLIS to ensure that the staff they recruited for the PEEF initiative would have access to a teacher librarian credential program. SLIS faculty and administration had prior experience in organizing general cohorts and management cohorts, as well as a wealth of proven expertise in delivering instruction using distance education technologies. The credential course of study lent itself easily to the formation of a cohort of school librarians. The cohort was selected by SFUSD for current or future school librarian positions within SFUSD. The students applied to the Masters of Library and Information Science (MLIS) at SLIS. SLIS set a minimum number of students needed to guarantee a cohort and created special sections of classes for the cohort. Instructors were hired and SLIS held a web conference orientation and introduction to the classes for the cohort in San Francisco.

The experiences of the participants are reported in the paper. The benefits realized by both cohort participants and by library and information science educators are examined. The perspectives vary from the administration of SFUSD to the coordination of a school librarian cohort at SLIS to the perspectives of instructors and students in the cohort. The group found the cohort to be successful in achieving the goal. The use of distance technologies removed far more barriers for the students than were created by the technologies. The cohort approach is a good match for the structured required course of study for the school librarian. The retention rates for the school librarian cohort are compared to those of other cohorts. The projected rate of completion is compared to those of other cohorts and the completion rate of non-cohort school librarians. Longer term plans and directions are discussed. The cohort experiences reported indicate the model is easily replicated and is sustainable over time.

\section{The Challenges of $21^{\text {st }}$ Century School Library Education}

Educating school librarians in the new millennium imposes many challenges in a university setting. Transmitting the core knowledge, core values, and philosophy of library and information science, while balancing the need to train library science students in new technologies that will enable them to deliver resources to their school communities, can be difficult. Librarians must master and transfer information literacy and technology skills to students and faculty, as well as support independent learning through individual or cooperative/collaborative research and projects. In the school library setting, technology changes the context of the roles to include the management of information in both physical and digital spaces. Knowledge management is more than an abstract notion but an everyday practice. It truly becomes an information ecology. The ability to search in a digital environment is of equal importance to search skills in a traditional environment for the school librarian. The distance education environment is further impacted by the issues and the relative comfort the school librarian student has with technology. 
Knowledge management is an essential part of the job responsibilities of a school librarian.. Knowledge management defined by Sallis and Jones (2002) as cited in Boelens (2007) is "the process of constructively using information and knowledge that is inherent in any organization...in order to enhance its performance, its management, and its operation." (p.37) Boelens (2007) speaks to the dilemma in her discussion of knowledge management in secondary school libraries. Schools and school systems today create, accumulate, and are bombarded by information in many forms, from library resources and statistics, to test scores, classroom management systems, digital curriculum information, and student information. The librarian's role is two-fold in Boelens view. First, managing print, non print, and digital resources housed in different areas within and outside of the school building so that the information can be accessed when needed is one area of responsibility. The second area of responsibility in knowledge management is teaching students and teachers to access information and to use the information to transform the information into knowledge useful to them. Knowledge management of this type will enhance student and faculty performance and provide a valuable service to the school community. According to Boelens, "the school information specialist is responsible for the acquisition, coordination, and management of the information and knowledge in many forms in the school." (p. 71) While the information comes in many formats, one of the roles of the school librarian will be to guide the faculty and students to relevant information regardless of format. Part of that guidance will come from constant retraining and lifelong learning. School librarians will have to be visible models of the kind of learning and information literacy skills they wish to teach.

Campello and Abreu (2005) suggest that school librarians are part of a new paradigm and "to contribute to the education of information-literate persons, the librarian himself or herself must be an information-literate person and master the skills needed to perform the search process properly." (p.38) Many of the traditional responsibilities of school librarians cannot disappear, such as instructing students in a classroom setting or working with individuals, and professional development for teachers. However, the librarian's role as manager of a physical space has morphed into managing library spaces in the physical, virtual, and digital realms with the attending challenge of staying current in knowledge of resources available and in information and technology literacy skills. School librarians need to demonstrate the information skills needed for effective searching. Campello and Abreu conducted a study of library science undergraduates based on Kahlthau's (1996) Information Search Process. The research results from Campello and Abreu suggest that "future librarians are not sufficiently prepared to perform the kind of research tasks for which they will be expected to act as mediators for others in the process of learning from information." (p. 49)

School librarians and teachers are a part of an information ecology in which online information search skills become increasingly important, at a time when sophisticated online search practices are not part of a typical teacher's repertoire of skills (Perrault, 2007). Minimal information search skill results in underutilization of resources that can enhance classroom and individual instruction. Ultimately, one of the goals of a school library graduate program is to produce "a library media specialist who has a distinct repertoire of skills, knowledge, and expertise about information-seeking and information literacy." (p.60) 
Haythornthwaite, Kazmer, Robins, and Shoemaker (2000) studied distance learning and community development among graduate library science students involved in the Library Education Experimental Program (LEEP) at the University of Illinois at Urbana Champaign through the Graduate School of Library and Information Science (GSLIS). Their research results suggest several factors contribute to creating a successful distance learning community. These include taking time to communicate and create bonding experiences for students during the first few semesters, especially during the first semester of the program, and establishing regular class meeting times. Instructors need to give constant detailed feedback during the first semester and design multiple methods of class interaction within the course content. Ultimately, the researchers felt that the graduate program was a success on two levels. The students mastered the course content and attained a degree in library science, while gaining technological expertise in distance education.

The SJSU cohort began as classroom teachers interested in becoming librarians or as classroom teachers placed in school libraries that had not been formally staffed for years. The cohorts had two immediate needs: to gain enough expertise to manage their assigned library facility or space and to become familiar with library canon, practice, philosophy, and methodology to become full-fledged librarians instead of classroom teachers placed in a library setting. A third need was less immediate, but was also vital. Coming from a school background, these classroom teachers needed a broad knowledge of all types of libraries and librarianship to satisfy the goals of the graduate program, and to benefit from the information ecology that existed in their communities. Knowing about the resources available to them beyond the walls of the school building is a form of knowledge management and gives the students valuable networking and resource opportunities. Working full-time, taking two courses per semester and learning new technologies was daunting for the participants.

\section{Administration of a Cohort for SFUSD}

The staff of SFUSD Textbooks, Libraries, and Media Services (TLMS) contacted SLIS in December 2006 about partnering with SLIS on a proposal to the Institute of Museum and Library Services (IMLS) for a cohort of school librarians. SLIS had written a similar grant in 2005 with a different partner school district, and SFUSD was hoping to replicate the grant. Based on the 2005 experience, the decision was made not to submit a grant because the time was not sufficient to prepare a credible proposal. However, in the discussions it was determined that the need of a proposal to start a cohort at SFUSD did not require a grant, although additional financial support would have been welcome. SFUSD and SLIS began to plan a cohort in January 2007.

The position in which SFUSD found them was unusual. The PEEF monies resulted in 15 new positions. Support for school libraries is uneven through the entire state of California. The number of individuals seeking credentials declined 28.6\% from 2002 to 2006. (Clark, Parker, \& Suckow, 2008) Given the unlikely prospect of recruiting fully credentialed librarians, the district turned to recruiting from within the district. They advertised for teachers interested in moving into the library. The credential laws allow for a district to issue an emergency credential in impacted areas provided the teacher is enrolled in an approved course of study for the credential. Since the new librarians would be working full-time, an online program was the best option. 
SLIS had experience in the past with cohorts, successfully implementing two different models. The first, called QuickStart SLIS, was designed to help a general population of students complete their required course work in their first term and then begin their specialization more quickly. The second, the Executive MLIS, was a better model for the school librarian cohort. The Executive MLIS is designed for individuals already in the library field in management positions, but lacking the MLIS degree. The course work is prescribed by SLIS and the cohort takes all of their course work in the same sequence as a group. The work on the IMLS grant also provided a framework for sequencing courses for the school librarian cohort.

A number of obstacles were overcome in the planning and implementation stage from January to August 2007. An early obstacle was the University schedule. It is typically planned a year in advance. The offerings for fall 2007 were not finalized and the courses for fall, LIBR 200 Information and Society and LIBR 233 School Library Media Centers, were added. Using the Executive MLIS model, a separate web page for scheduling was created for the cohort. Again, using the Executive MLIS model, the students did not have to schedule themselves; SLIS office staff enrolled them in classes. If the cohort did not make the minimum number for enrollment, the courses would have been removed from the fall schedule. Based on experience with a wide variety of online classes, 14 students had been determined as the minimum number for the cohort. SLIS also had to adjust the University application to include the cohort to allow office staff to track applications.

At the same time, SFUSD was screening candidates and helping principals make their hiring decisions for fall. The hiring decisions were complicated by state and district budget approvals for fall plus determining the number of replacements needed for retiring librarians and for resignations. The deadline for fall registration was March 31, 2007 and potential students were not sure if they would be hired. They were reluctant to begin the application process without the guarantee of a school library position. To relieve the application issues, SLIS found a way to extend the deadline for an additional ten days in April. Prospective students had to apply and then present the documents to support their application. In the end, 25 students were able to apply for the cohort. All of them were accepted but the acceptance process for some of them was not complete until late July.

SFUSD meets regularly with all of their librarians, and through these meetings, brochures were distributed and information about the cohort was communicated. In March 2007, one general information meeting was conducted jointly by SFUSD and SLIS. Over 50 people attended the meeting and the number of interested school librarian candidates virtually assured that the cohort would attain the minimum number of students. At the same meeting SFUSD human resources personnel, answered questions about the emergency certificate and a member of the SLIS faculty provided an overview of the program and what the journey would be like for the students. Following the meeting, SFUSD monitored the students' application submissions and a list of applicants and acceptance, was managed by SLIS to insure an accurate student roster for the cohort.

Following the March meeting, SLIS hired instructors for the first two terms of the cohort. Three were part-time faculty and the fourth was a full-time tenured faculty member. The three part-time faculty had not taught for SLIS before. The process of developing the courses for fall 
continued through the summer, using the syllabi of existing courses as models. In the fall one instructor for spring was able to shadow a class through the entire semester to prepare for the class. The instructors also had to become familiar with the distance education tools, taking the faculty course on technology to be ready for the first day of the term. None of the faculty teaching the first four classes lived in California and three of them were in the Eastern time zone.

After a summer of preparation and work, the cohort was ready to begin their course work. On August 20, 2007, SFUSD arranged a meeting for all of the members of the cohort and a representative from SLIS in one of the meeting rooms at the main branch of the San Francisco Public Library. In the morning they were given an abbreviated version of the new student orientation and were able to ask questions about the cohort and SLIS. After lunch, the instructors for LIBR 200 and LIBR 233 linked to the meeting using Elluminate, the SLIS web conferencing tool, and introduced themselves and the course work to the class. Twenty-five students began LIBR 200 and 28 began LIBR 233. SFUSD had asked for exceptions for students needing the class to complete their credential.

\section{Online Coursework for the SFUSD Cohort}

The MLIS and the Teacher Librarian (TL) Services credential for the SFUSD cohort is a total of 42 credit hours. The first 36 hours meet the required course work of the specified course of study approved by the Commission on Teacher Credentialing (CTC). The TL services credential is a second credential. It is issued by the CTC upon the completion of the course of study to holders of a first credential, either a single subject or multiple subject teaching credential. Credential candidates also have to pass the CBEST and they must be recommended by an institution of higher education in California offering the TL preparation program. The members of the cohort all met these requirements. The cohort will complete their credential coursework first and then complete the MLIS. Students also completed the mandatory New Student Technology Workshop, a self-paced online tutorial.

\section{Technology Tools}

Online coursework for the SFUSD cohort began in the fall 2007 semester as students enrolled in two introductory classes at SJSU: LIBR 200 (Information and Society) and LIBR 233 (School Library Media Centers). Instructors for these courses included Linda Swarlis and Margaret Lincoln who had both recently been a part of a distant-independent interdisciplinary information science doctoral program at the University of North Texas. In addition to their personal experience with the cohort model, Swarlis and Lincoln were veteran practicing school library media specialists. Both courses are required for the Master's in Library and Information Science (MLIS) degree and the teacher Librarian Services credential. The LIBR 200 course explores the complex social, economic, historical, and technological developments that influence the impact of information on society and analyzes the mission, values and ethics of information professionals. The LIBR 233 course explores the role of the school library media teacher and the school library media program in the educational community and emphasizes the creation of effective learning environments, involvement in the curriculum and teaching process, as well as philosophies of service and management. The design of the online sections of LIBR 200 and 233 took place throughout the summer months prior to the start of the fall 2007 semester. As new faculty members, Lincoln and Swarlis were able to take a two-week overview course for 
teaching online via the Blackboard Content Management System and Elluminate, a collaborative and real-time virtual environment. Not only did this course for new faculty cover the basic technical components of Blackboard and Elluminate, but also the pedagogical issues of online learning were addressed from the perspective of teacher and student. With support from such extremely knowledgeable individuals as Debra Faires, Dale David, Stanley Laufer, and Gina Lee in the SLIS IT Department, an online course site was created. SLIS faculty colleagues Dr. Blanche Woolls and Dr. Celeste Nalwasky, highly respected for their own successful teaching of LIBR 200 and 233, shared valuable suggestions for content integration.

\section{Course Design of LIBR 200}

Information and Society is the overview course for the MLIS and the TL Services credential. It was the first of three required foundation courses studied by the cohort. The course is designed to address core competencies of SLIS graduates. The specific competencies include a wide variety of concepts, including the promotion of intellectual freedom, ethics, values and foundational principles of library and information professionals. The course also introduces environments and organizational settings in which library and information professionals practice the social, cultural and economic dimensions of information use. Finally, all students are expected to demonstrate oral and written communication skills necessary for group work, collaborations and professional level presentations. The course is a keystone of the MLIS program and the TL Services credential and is used as a transition point for the evaluation of student fitness in the field of Library and Information Science. It sets the theoretical foundation for the rest of the student's program.

\section{LIBR 200 Course Outcomes and Assessments}

\begin{tabular}{ll}
\hline Outcome & Assessment \\
\hline $\begin{array}{l}\text { Know the foundations and structure of the } \\
\text { information profession; }\end{array}$ & $\begin{array}{l}\text { All students will participate in a group project } \\
\text { that surveys the information professions and } \\
\text { report the findings to the class. }\end{array}$ \\
\hline $\begin{array}{l}\text { Locate, evaluate, and utilize scholarly and } \\
\text { professional literature; }\end{array}$ & $\begin{array}{l}\text { All students will be required to write critical } \\
\text { notes for publications pertinent to library and } \\
\text { information science. They will use APA in } \\
\text { completing these assignments. }\end{array}$ \\
\hline $\begin{array}{l}\text { Demonstrate in-depth understanding of } \\
\text { major issues in library and information } \\
\text { science }\end{array}$ & $\begin{array}{l}\text { Students are required to research and write a } \\
\text { major paper (worth 30\% of their total grade) on } \\
\text { a topic relating to information and society. } \\
\text { They will use APA in writing all papers in this } \\
\text { class. }\end{array}$ \\
\hline
\end{tabular}




\section{Implementation of LIBR 200}

The course management system, Blackboard, allowed the instructor and the students to participate in the class at times most convenient to them. Students posted answers to the threaded discussion questions using information gleaned from their readings. Students also posted two critical notes in which they critiqued a professional or scholarly article. Class members were expected to respond to the posted critique. Assignments were posted on Blackboard along with relevant course information and additional resources. Students also posted a group assignment to the discussion board on library and information science periodicals and professional associations. A digital drop box was used to submit individual and group assignments including a special populations paper, the major paper, a resume, and a valuing the professional paper.

Elluminate allowed for communication in parallel time (twice a month scheduled Elluminate meeting times) for class presentations, lectures, and question and answer sessions, as well as non-parallel communication for viewing and reviewing missed presentations and lectures. As part of the 200 course requirements, students needed to be evaluated on both written work and oral presentations. Using Elluminate as one form of class communication gave each member of the class two opportunities to present to a large audience through a webcam. For almost all of the students, the webcam was a new technology to master. The SJSU technology staff members were phenomenal in providing support for any class member wishing to practice and scheduled additional sessions to ensure that every student felt comfortable with the technology before their presentations. Each student prepared and presented an individual introduction of a library luminary. Each class member also participated in a group presentation on information professionals and the type of library in which they were employed.

At times, the broad focus of the Information and Society course appeared to be at odds with the pragmatic needs of the cohort and caused some frustration. Examining the world of library and information science through a larger lens proved beneficial in the long run as the cohort members developed a greater understanding and appreciation of different types of libraries and the current issues in library and information science. Through their research, several of the cohort members became aware of resources available to them through area libraries and were able to use those resources in their own library settings

The design, implementation, and evaluation of the LIBR 233 course within the context of the SFUSD Cohort are discussed in the following sections of this paper.

\section{Course Design of LIBR 233}

The preparation for LIBR 233 for the SFUSD cohort required meeting specific instructional objectives and to support SLIS core competencies. The assignments were designed to provide students with practical, job-related learning experiences that would have a positive impact as they began their careers as library media teachers. As summarized in Table 1, the LIBR 233 syllabus explained how course outcomes would be realized and assessed through the completion of specific assignments.

Table 1 
Outcome Assessment

Students will know the principles and practices of managing a school library media center. a. Students will prepare a promotional brochure, outlining and explaining the library media center program. At a later date during the course, students will present this item to a state legislator or community leader. (Unit 1 and follow-up)

b. Students will identify, locate and collect a sampling of policies and procedures used in the management of a school library media center (such as a materials selection policy) and will customize one policy or procedure to reflect practice in their own school library media center. (Unit 2)

\section{Outcome \\ Assessment}

Students will be able to locate, evaluate, and utilize scholarly and professional literature.

Students will exhibit effective oral and written communication skills in collaborative projects.

Students will demonstrate an understanding of how to integrate technology applications into information management. a. Students will search for, locate, read and critically review articles in publications pertinent to library and information science. (Units 2-7)

b. Students will report on and share more informal posts found in blogs and other Web 2.0 applications as pertinent to library and information science. (Units 2-7)

c. Students will evaluate and submit a recommendation for a new technology tool. (Units 3)

a. Students will plan a project promoting recreational reading and will present this project idea to colleagues in a staff meeting. (Unit 4)

b. Students will work jointly to prepare and submit a grant proposal for funding a library project (Unit 5)

a. Students will work with a teacher colleague to modify a lesson plan so as to incorporate library media center resources and reinforce information literacy skills. (Unit 6)

b. Students will design a Library Web portal giving access to the media center's real and virtual presence. (Unit 7) 


\section{Implementation of LIBR 233}

Following the August 20, 2007 web conference orientation session for students and instructors, the LIBR 233 Blackboard site was officially launched and coursework began. The students quickly became comfortable navigating the components of Blackboard. Emphasis was placed on communicating the details of project-based work, as recommended by Pribesh, Dickinson, and Bucher (2006) in a study comparing online and face-to-face cohorts in a school library media specialist graduate program.

Students regularly checked the Announcement section of Blackboard (Figure 1). Students then proceeded to the Course Documents section (Figure 2) where color-coded folders grouped PowerPoint presentations, links to recorded Elluminate sessions, assignments, and related handouts needed for each of LIBR 233's units. Figure 3 provides an example of the contents of the Unit 1 folder.

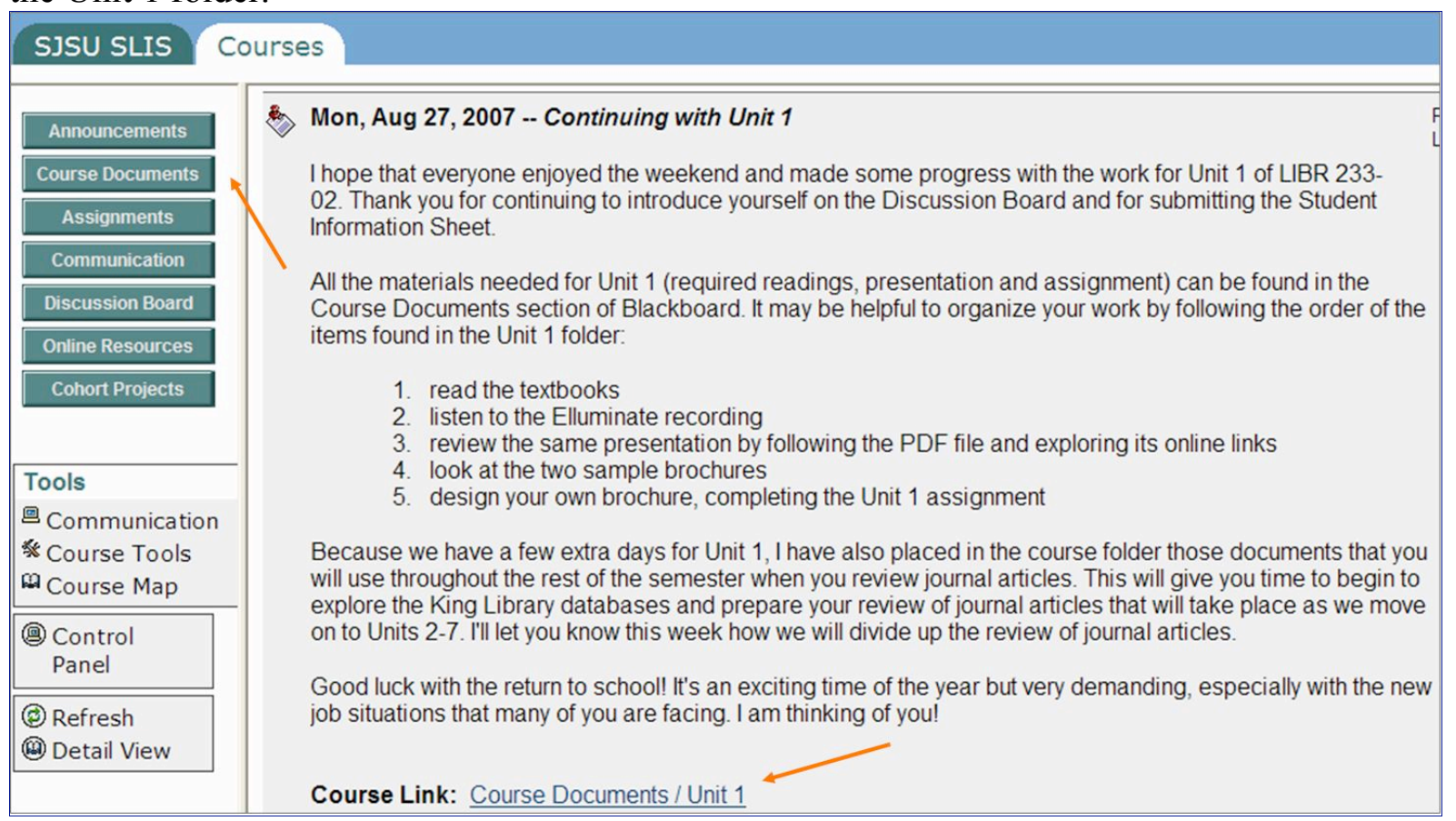

Figure 1. Blackboard Announcement directing students to Course Documents. 


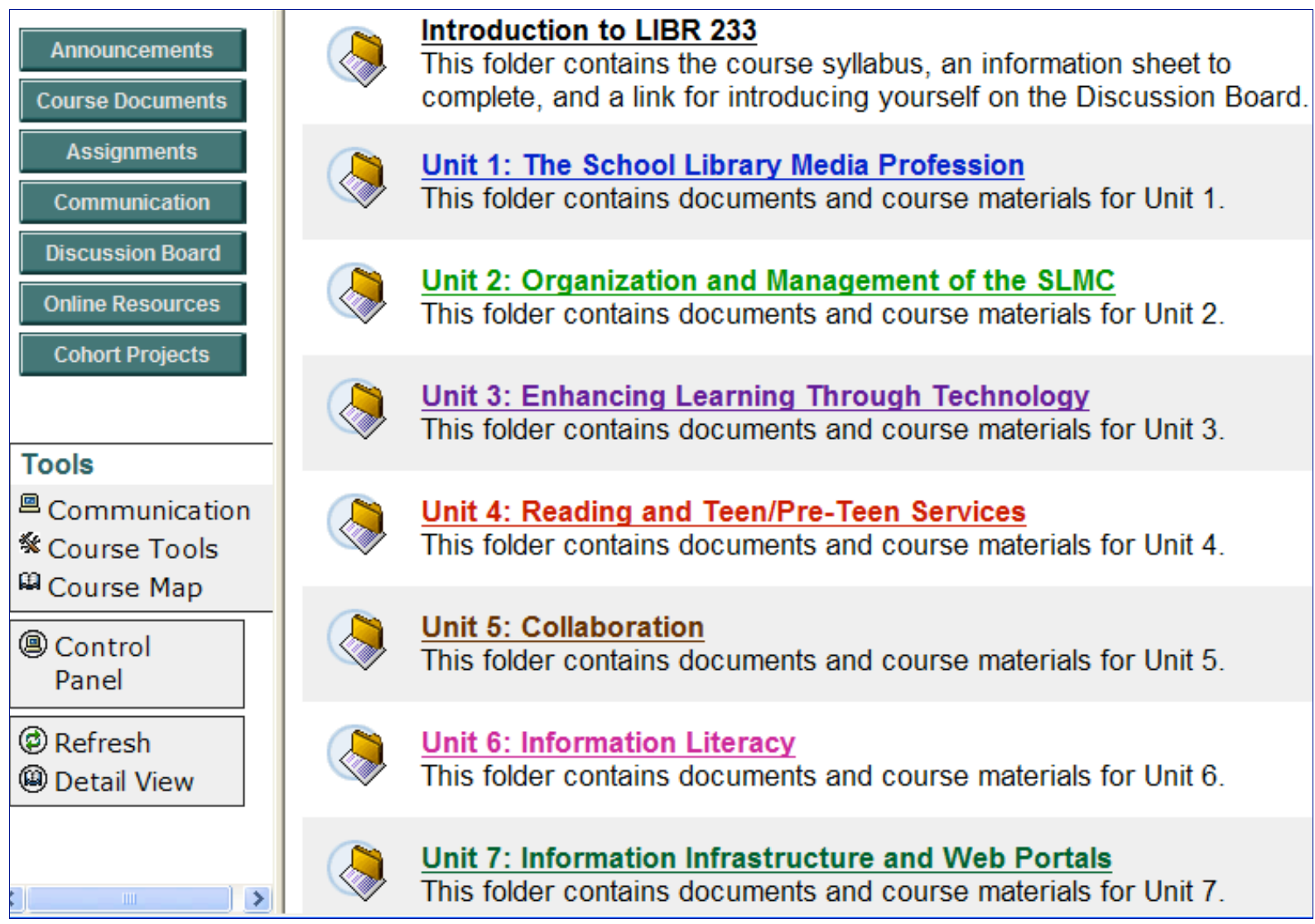

Figure 2. Course Documents folders (color-coded) for units.

Unit 1
Revised Brochure Assignment Unit 1
BrochureAssignmentRev.doc ( $69.5 \mathrm{~Kb}$ )
The brochure is due by $11: 00 \mathrm{PM}$ (Pacific Time) on 09/09/07. A summary of your
meeting must be posted to the Discussion Board on Blackboard by $12 / 02 / 07$.
Assigned Readings Unit 1
Woolls, Blanche. The School Library Media Manager: Chapters 1 and 2.
Information Power: Building Partnerships for Learning: Preface, Introduction, and
Chapter 1.
Presentation Unit 1 (Elluminate Recording)
This School Library Media Profession Unit 1 presentation opens as an Elluminate
recording.
Presentation Unit 1 (Pdf file)
Unit 1 presentation (PDF) ( 842.6 Kb)
This School Library Media Profession Unit 1 presentation opens as a PDF file.
Joyce Valenza Sample Brochure 1
Sample Brochure 1 (148.5 Kb)

Figure 3. Unit 1 Course Documents folder contents. 
As a unit was completed and as assignments were uploaded to Blackboard, exemplary work by LIBR 233 students was shared through the Cohort Projects section of the course site. Figure 4 displays a sample school library media center brochure created for a Unit 1 assignment.

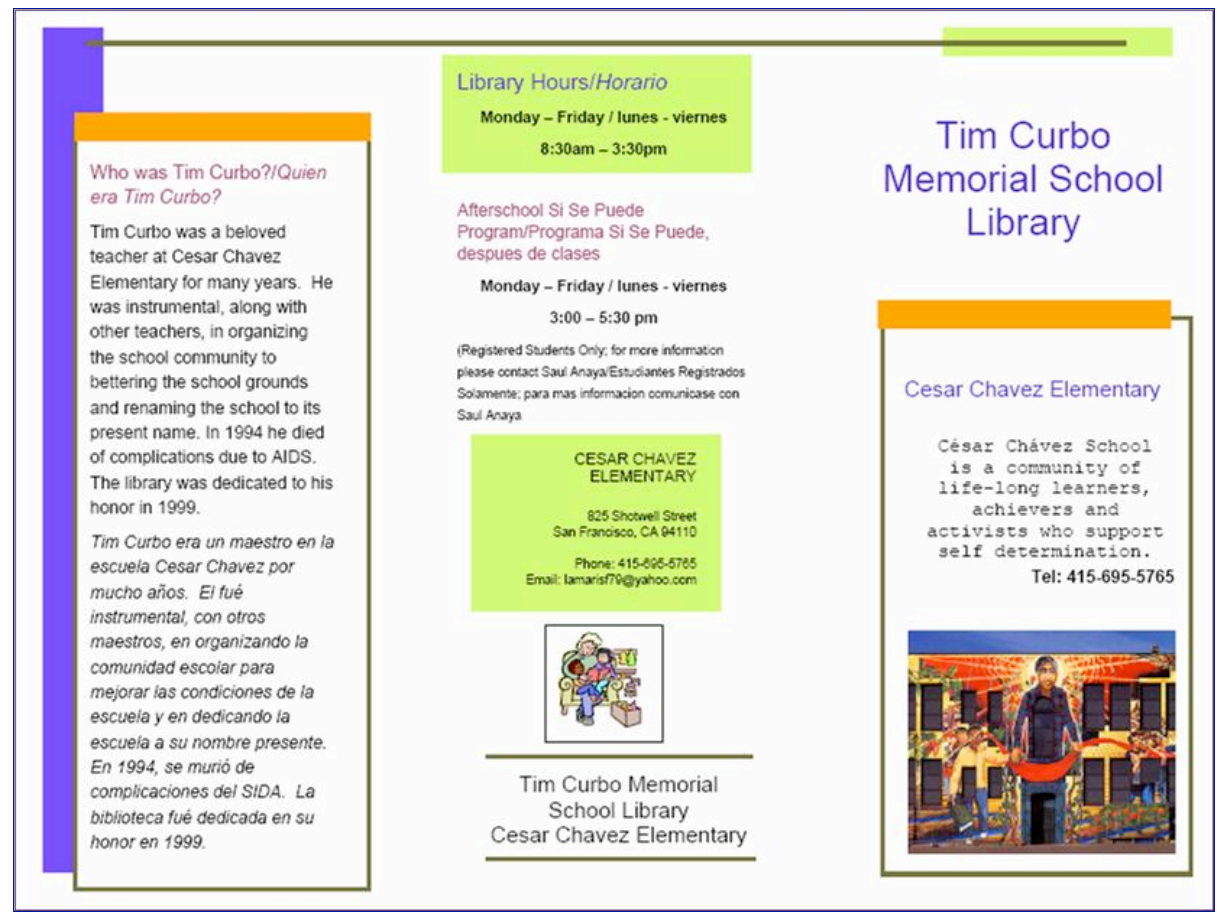

Figure 4. Sample SLMC brochure displayed in Cohort Projects section of Blackboard.

Throughout the semester, an ongoing assignment involved reading and reviewing journal articles related to each unit. Groups, with four to five students each, shared professional and peer-reviewed articles on the Discussion Board section of Blackboard. The groups were responsible for leading the conversation about these articles and relating the articles to the main topic of each unit. When a student was not assigned the role of moderator, he/she was still expected to participate in the discussion of articles for the unit by posting comments to Blackboard. Although the exchange of comments was asynchronous, the discussion exhibited such characteristics as frequency, intensity and topicality as reported on in a 2007 study by Burnett, Bonnici, Miksa, and Kim (2007).

The use of real-time virtual meetings on Elluminate provided another dimension to course activities. In addition to instructor-led sessions designed to clarify course content expectations and to respond to questions about assignments, guest lecturers participated using Elluminate. For example, expanding upon the topic of Unit 3: Enhancing Learning Through Technology, Dr. Michael Stephens (blog creator of Tame the Web and an assistant professor at Dominican University) gave a presentation on Web 2.0 tools. Rob Darrow, coordinator of Instructional Resources and Library Services in California's Clovis Unified School District and a Big6 $^{\mathrm{TM}}$ trainer, delivered an Elluminate session in conjunction with the Information Literacy unit. Dr. Joyce Valenza presented the topic of virtual libraries. Recordings were made of all Elluminate meetings so that students unable to participate in real-time could still access the 
archived session. Figure 5 shows how this session utilized Elluminate's interactive polling feature.

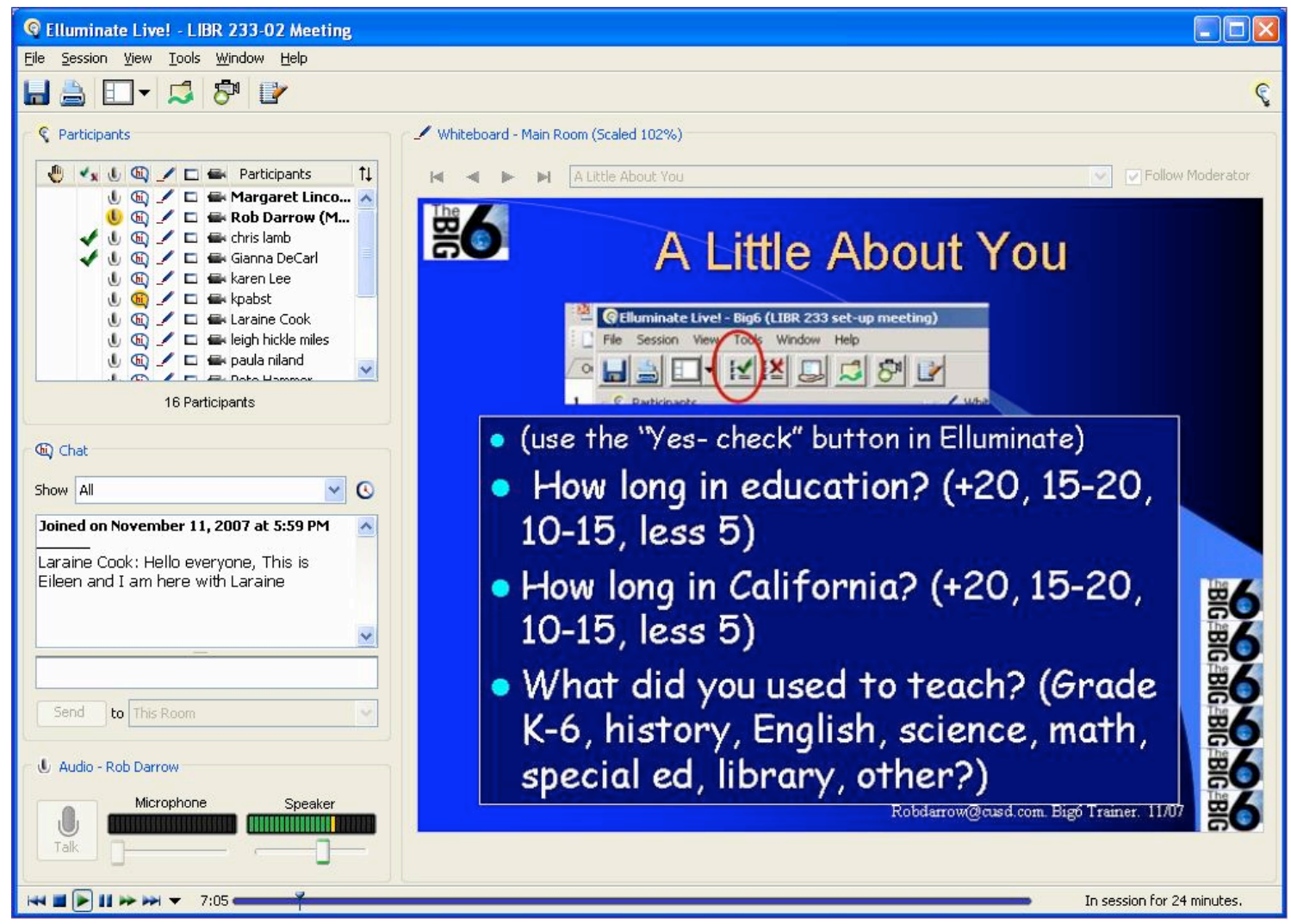

Figure 5. Elluminate session with guest presenter Rob Darrow.

\section{Discussion of the Cohort}

As the authors prepared this paper, they found themselves reflecting on the cohort approach and the coursework. In the discussion, the assessment, costs, retention, and future directions for research are highlighted. Accrediting agencies are concerned about the fitness or disposition of the credential candidate for the profession. The discussion of evaluation reviews and the assessment tools apply only to the credential and not to the larger issues of a MLIS. Costs are discussed from the perspective of the internal impacts on the organizations and what the students faced in their personal lives. Retention is focused on the transition from the first term to the second and it is compared to other cohorts conducted by SLIS. The authors' thoughts on future areas of research expand upon these topics.

\section{Course Evaluations}

Course evaluation of LIBR 233 was accomplished through several means. A Part-Time Faculty Peer Review was conducted, providing recommendations and feedback for instructor Margaret Lincoln. In so far as a Blackboard course site remains accessible to SJSU faculty at the conclusion of a semester, modifications and improvements can thus be made to a course based upon the Peer Review. Similarly, comments received from students through their completion of 
the Student Opinion of Teaching Effectiveness Survey (SOTES) can be helpful as course content and methodology are updated. Overall, both LIBR 200 and LIBR 233 were positively evaluated. A representative comment from the SOTES instrument is given below:

Each assignment was applicable and useful to our everyday practice, with clearly defined expectations and was laid out with incredible organization in the online environment. Much time and effort was put into lifting us new librarians into an elevated realm of librarianship. All this was done with enthusiasm, understanding and respect for each of us as individuals.

In addition to the above methods of formal evaluation, anecdotal evidence of favorable outcomes associated with SFUSD coursework can be mentioned. Several grant proposals written by students as part of an LIBR 233 assignment were actually submitted to potential funding sources and approved. For example, an attempt to secure funds for a book club for low literacy high school students was successful as was a proposal to automate an elementary library media center.

Another assignment with real-world applicability required students to meet with a legislator or community leader. This assignment supported the recommendation put forth by Moreillon and Misakian (2007) to integrate opportunities for advocacy learning into library school coursework. As a result of issues raised during one such meeting with a San Francisco Supervisor, a hearing on the status of SFUSD libraries was held in February 2008. Cohort members and SFUSD library administrative personnel provided testimony about the outstanding work being accomplished by school library media teachers in the newly resurrected positions funded by Proposition $\mathrm{H}$.

\section{Retention}

A surprising finding about the school library cohort is the comparison of students who are retained in the cohort from the first term to the second. The experience of SLIS has been that the largest amounts of students make their decision to stay with the cohort at the point where they are registered for their second term of courses. The cohort of school librarians had a much lower retention rate than other cohorts from the SLIS experience (Figure 6). There are three possible factors impacting this variance in retention. One would be the structure of the emergency credential process. There is no incentive to the credential candidate to move quickly through the program. Only six credits are needed each year to keep the emergency credential in force plus it can be renewed annually up to five times. A second factor is the rigor of the MLIS. Students who left, indicated anecdotally they were having difficulty balancing their lives. A third factor is working a new position with no experience in the new environment. 


\begin{tabular}{|l|l|l|l|l|}
\hline Cohort & $\begin{array}{l}\text { \# of Students } \\
\text { Beginning of } 1^{\text {st }} \\
\text { Term }\end{array}$ & $\begin{array}{l}\text { \# of Students } \\
\text { Beginning of } 2^{\text {nd }} \\
\text { Term }\end{array}$ & Drops & Retention \% \\
\hline QS 1 & 45 & 43 & 2 & $95.5 \%$ \\
\hline QS 2 & 36 & 34 & 2 & $91.9 \%$ \\
\hline QS 3 & 29 & 26 & 3 & $89.6 \%$ \\
\hline EX 1 & 12 & 12 & 0 & $100 \%$ \\
\hline TL 1 & 27 & 17 & 10 & $69.3 \%$ \\
\hline
\end{tabular}

Figure 6 Comparison of cohort retention from first term to second term

Costs

The financial costs of participating in the cohort divided the students into two groups. One group, those who stayed with the cohort, wants to maximize their investment and want to take the maximum number of courses possible. The second group, those who left, does not see a large problem with the cost of paying for one class when they could take two for the same fee. SLIS monitors the relative cost of the program both nationally and in California. The fees are consistently the least expensive in both comparisons.

The hidden costs are not clear but appear to be substantial. In reflecting and reviewing the process by which the cohort was put together, the number of people who had to be involved was surprising. At one point individuals from the University Information Technology staff had to make changes in the programming of the application process to accommodate the cohort. No effort was taken to quantify the time and efforts of staff related to the cohort outside of their normal routine. It needs to be quantified and examined. One reason the appearance of a substantial administrative cost associated with the cohort was the short time frame the cohort was planned and implemented. It created emergency situations instead of planned work for staff.

\section{Future research}

One area not examined was the satisfaction of the students and the faculty. The students evaluated their instructors as part of the University's standard course evaluation practices. These are general in nature and do not look for the specific aspects and issues of concern to a cohort. The satisfaction of faculty and staff has to be considered also and the various cohorts should be compared to each other.

A second area of research would be finding the costs of the cohort and comparing it to the standard method of offering courses to students. Anecdotally, staff members indicated that it took more effort to create and maintain a cohort. The costs and benefits have to be quantified and examined.

A more thorough examination of retention is needed. The large variance and a possible explanation of the variance need to be tested and evaluated. 


\section{Conclusion}

Despite the precarious state of money available for education, the SFUSD library positions should remain intact through 2012. In the meantime, members of the SFUSD Cohort continue with SLIS coursework, in pursuit of the MLIS degree and the Teacher Librarian Services Credential, while supporting meaningful teaching and learning in San Francisco Public Schools.

A credential program is easily adapted to a cohort model and the cohort model does allow for proactive resource planning for University administrators. University administrators can schedule instructors several terms in advance to teach the required course work. This cohort model may not be the best match for the current manner in which the state of California issues credentials. Emergency credentials be granted to students working in schools. The building principal is the de facto evaluator of the fitness of a candidate for the library profession, and does not require the approval through the library program. The low bar to get and maintain the emergency credential is a disincentive for candidates to move quickly through a preparation program. If district administrators want to move more quickly to have a faculty that complies with credentialing law, they are at a disadvantage.

The cohort model has moved the SFUSD group forward on their credential work and the MLIS degree. The citizens of San Francisco can feel their money is being spent wisely to open closed libraries in their public schools. It is a welcome trend in a state where the school libraries rank near the bottom of the list when compared to other states. Technology played a significant

role in the first steps to prepare world-class school librarians to deliver learning and literacy to their students.

\section{References}

Boelens, H. (2007). Knowledge management in secondary schools and the role of the school librarian. School Libraries Worldwide, 13(2), 63-72.

Burnett, K., Bonnici, L., Miksa, S., \& Kim, J. (2007). Frequency, Intensity and Topicality in Online Learning: An Exploration of the Interaction Dimensions that Contribute to Student Satisfaction in Online Learning. Journal of Education for Library and Information Science, 48(1), 21-35.

Campello, B. \& Abreu, V. L. F. G. (2005). Information literacy and the education of school librarians. School Libraries Worldwide, 11(1), 37-52.

Clark, T, Parker, R, and Suckow, M. (2008) Services Credentials Issued in California 2001-02 to 2005-06. Sacramento, CA: Commission on Teacher Credentialing.

Haythornthwaite, C., Kazmer, M. M., Robins, J. \& Shoemaker, S. Community development among distance learners: Temporal and technological dimensions. Journal of Computer-Mediated Education, 6(1). http://jcmc.indiana.edu/vol6/issuel/haythornthwaite.html 
Kuhlthau, C. C. (1996). Seeking meaning: A process approach to library and information services. Norwood, NJ: Ablex.

Moreillon, J., \& Misakian, J. (2007). Preservice Teacher-Librarian Education: Learning the Character of an Advocate. Knowledge Quest, 36(1), 20-3.

Perrault, A. M. (2007). The school as an information ecology: A framework for studying changes in information use. School Libraries Worldwide, 13(2), 49-62.

Pribesh, S., Dickinson, G., \& Bucher, K. (2006). A Comparison of Online and Face-to-Face Cohorts in a School Library Media Specialist Graduate Program: A Preliminary Study. Journal of Education for Library and Information Science, 47(4), 303-23.

Sallis, E. \& Jones, G. (2002). Knowledge management in education: Enhancing learning and education. London: Kogan Page.

\section{Biographical Notes}

Daniel Fuller is an Assistant Professor in the School of Library and Information Science at San José State University. He earned a Ph.D. from the University of Pittsburgh in 1991 and has worked as a high school librarian and in the software industry. Dr. Fuller coordinates the Teacher Librarian Services credential and teaches management and technology at SLIS. He conducts research in distance education, information technology, and management.

Margaret Lincoln is a lecturer in the School of Library and Information Science at San José State University, a library media specialist at Lakeview High School in Battle Creek, Michigan and a database trainer for the Library of Michigan. She earned a Ph.D. in library and information sciences from the University of North Texas in 2006. Dr. Lincoln's research interests focus on information literacy and instruction, school library media centers, Holocaust education, and museum informatics. She was a 2000 American Memory Fellow with the Library of Congress and a 2002 Mandel Teacher Fellow with the United States Holocaust Memorial Museum.

Linda Swarlis is a lecturer in the School of Library and Information Science at San José State University, a Director of Information Services and Library at Columbus School for Girls and Curriculum Council Chair, in Columbus, Ohio and a library and information science distance independent doctoral cohort member at the University of North Texas. Ms. Swarlis has experience as a librarian at all three levels: elementary, middle school, and high school in both public and private schools. Her research interests include spatial ability and its relationship to information seeking and gender issues in the use of technology

\section{Statement of Originality}

This is to certify that the paper above is based upon original research undertaken by the authors and that the paper was conceived and written by the authors alone and has not been published elsewhere. All information and ideas from others is referenced. 